\title{
Kadına Yönelik Şiddet Temalı Kamu Spotlarının Göstergebilimsel
}

\section{Çözümlemesi}

\author{
Semiotic Analysis of Public Service Announcements on Themed Violence Against \\ Women
}

\author{
Dr. Öğr. Üyesi Canay UMUNÇ (iD) 1
}

\begin{abstract}
$\ddot{O} z$
Kamu spotu, kamu yararına hazırlanan bilgilendirici ve eğitici nitelikte ses ve filmlerdir. Kamu spotları aracılığılyla verilen mesajlar kanaatlerin yönlendirilmesinde ve değişiminde büyük öneme sahiptir. Bu amaçla sağlık, çevrecilik, güvenlik vb. toplumsal sorunlara yönelik hazırlanan kamu spotları ile topluma mesajlar verilerek bu sorunlar çözülmeye çalışılmaktadır. Ülkemizde kadına yönelik şiddet temel bir toplumsal sorundur. Bu sorunun psikolojik, ekonomik, fiziksel vd. türleri vardır ve bunların çözümü için medya çalışmaları da dahil birçok alanda çalışma yapılması gerekmektedir. Bu çalışmalar kapsamında, ilgili kurum ve kuruluşlar tarafından çeşitli kamu spotları hazırlanmaktadır. Bu çalışmada, T.C. Aile ve Sosyal Politikalar Bakanlığı ve Kadın ve Demokrasi Derneği (KADEM) tarafından hazırlanan kadına yönelik şiddet temalı kamu spotlarının göstergebilimsel çözümlemesi yapılmıştır. Böylelikle, kamu spotlarında, cinsiyetlerin konumlandırılışı, söylem ve anlam düzeylerinde verilmek istenen mesaj, gizli anlam ve imalar ortaya çıkarılmaya çalışılmıştır. Çalışmanın sonucunda, kamu spotu anlatılarında kadına yönelik şiddetin çözümü için erkek davranışlarının değişmesi gerektiği fikkrinin ağırlıklı olarak vurgulandığı, sorunun toplumsal, psikolojik ve ekonomik boyutlarının yeterince sunulmadığı görülmüştür. Sonuç olarak, hazırlanan kamu spotlarının şiddete yönelik söylemlerini bu unsurları göz önüne alarak oluşturmasıyla, şiddet sorununun çözümünde daha etkili olacağı düşünülmektedir.
\end{abstract}

Anahtar Kelimeler: Kamu spotu, kadına yönelik şiddet, toplumsal cinsiyet, göstergebilim

Makale Türü: Derleme

\begin{abstract}
Public service announcement is informative and educational sound and films prepared for public interest. The messages given through public service announcements have great importance in the direction and change of opinions. For this purpose, by giving messages to society with public service announcements prepared for social problems as health, environmentalism, security exc., these problems tried to be solved. In our country, violence against women is a fundamental social problem. There are psychological, economic, physical and other types of this problem and there is a need to work in many areas, including media studies for solving them. Within the context of these studies, various public service announcements are prepared by related institutions and organizations. İn this study, it has been made semiotic analysis of public service announcements themed violence against women prepared by Turkish Family and Social Policies Ministry and Women and Democracy Association. Thus, it was tried to reveal the message, hidden meaning and implications in gender, discourse and meaning levels in public service announcements. As a result of the study, it was observed that the idea that male behaviors should be changed in the solution of violence against women in psa narratives and the social, psychological and economic dimensions of the problem are not adequately presented.
\end{abstract}

Keywords: Public service announcements, violence against women, gender, semiotics

Paper Type: Review

${ }^{1}$ Niğde Ömer Halisdemir Üniversitesi, İletişim Fakültesi, canayumunc@ ohu.edu.tr.

Atıf için (to cite): Umunç, C. (2019). Kadına Yönelik Şiddet Temalı Kamu Spotlarının Göstergebilimsel Çözümlemesi. Afyon Kocatepe Üniversitesi Sosyal Bilimler Dergisi, 21(4), 1316-1334. 


\section{Giriş}

Kamu spotu, televizyon, radyo ve basılı yayın gibi çeşitli medya kanallarında gösterilebilen, ödemesiz bir reklamdır (Staggers ve Myers, 2011:213). Kamu spotları, kamuoyunu bilgilendirme, sağlık, güvenlik ve etkinlik tanıtımı vb. alanlarda önerilerde bulunma, yardım toplama faaliyetlerine toplumu teşvik etme gibi hedeflerle kamu yararının gözetilmesi için kullanılmaktadır (Bütün ve vd., 2018: 274). Kamu spotları, faaliyetlerin veya programların tanıtımlarını yaparak belirli bir konu hakkında kamuoyunu bilinçlendirmeyi amaçlamaktadır (Staggers ve Myers, 2011:213). Kamuoyunun, internet, gazete haberleri, hükümet bildirileri, resmi açıklamalar vd. araçlar vasıtasıyla devletin çeşitli alanlardaki politikalarıyla ilgili bilgi ve izlenimlerini elde ettiği gibi, kamu spotları ile iletilen mesajlar da önem arz etmektedir.

Kamu spotları, birçok iletişim kampanyasının önemli bir öğesidir ve inandırma gücünün yanı sıra toplumu ilgilendiren meselelerde pek çok izleyicide duygusal bir tepki uyandırmaktadır (Dillard, Peck: 2014:461). Kamu spotlarının hedeflenen ve sürdürülebilir sosyal yanlı davranışları nasıl oluşturabildiğine dair kapsamlı bir literatür bulunmaktadır. (Griskevicius, Cialdini, ve Goldstein 2008; Bator ve Cialdini 2000; Cialdini 2003).

Olumlu sosyal davranışları teşvik etmek için çeşitli çabalar mevcuttur ama insanlar ne zaman kitle medyası ve sağlık mesajlarını düşünse, kamu spotlarını akıllarına getirmektedir. Kamu spotlarının süresi kısadır (genellikle bir dakikadan azdır) ve basit ama akılda kalıcı mesajlarla geniş kitlelere ulaşmaya çalışır. Kamu spotları, bilgi verebilir, ikna edebilir veya olumlu ve sağlıklı davranışları motive edebilir. İlkin, kitle medyası, mesajları, toplum sağlığı konularında bilgi ve farkındalığı geniş çevrelere yayabilir. İkincisi, kamu spotları davranışları etkileme yetisine sahiptir (normatif inançları değiştirme, sempati uyandırma veya mesaj alıcıları arasında korku seviyesini arttırma gibi). Tutumları etkilemenin bir yöntemi, diş sağlığı, güvenli sürüş, sigara kullanımı, alkolizm ve AIDS için sağlık kampanyalarında görüldüğü gibi korku çekiciliğini dahil etmektir. Çok dramatik ve korkutucu görüntüleri görerek oluşan endişeleri azaltmak için, insanlar bazı sağlık sorunları ile ilgili tutumlarını değiştirebilir. Üçüncüsü sağlık mesajlarına maruz kalma davranış değişikliği sağlar. Stanford Üç Topluluk ve Beş Şehir Projesi'nin sonuçlarının analizinde görüldüğü gibi, kamu spotları değişmeye hazır olanlar arasında sağlık değişikliklerini (yani diyet değişiklikleri, sigarayı bırakma, fiziksel aktiviteyi arttırma) teşvik etmiş ve daha önce değişiklik yapanlar arasında bu tutumları güçlendirmiştir. 30 saniyelik formatta bile, bilgilendirici ve duygusal çağrılar, daha sağlıklı yaşam tarzlarına adım atmak için izleyiciye teknikler ve tavsiyeler sunmaktadır ( Dina vd. 1999:181)

İletişim alımında dört bağımlı değişken önemli rol oynamaktadır. Bunlar, ilgi, anlaşılabilirlik, güvenilirlik ve algılanan etkidir. İlk hipotez, şiddet karşıtı kamu spotlarının söz konusu değişkenlerinin, cinsiyet, etnik yapı ve coğrafya gibi kişisel özelliklere göre değişeceği şeklindedir. İkinci hipotez, şiddetle ilgili bilgi, tutum ve deneyimler de kamu spotlarını algılama ile ilgilidir. Bilgi üzerine çalışmalar, belirli bir konuda önceden var olan bilgilerin, mesajı algılamaya etki edebileceğini göstermektedir. Eğer mevcut bilgi, sunulan bilgiden farkliysa ve bilişsel uyumsuzluk uyandırıyorsa, mesajın etki oluşturması düşük bir olasılıktır. Buna karşı1ık, temel bilgiye sahip olanlar daha fazla bilgi edinmeye, tutumlarını veya davranışlarını değiştirmeye ikna edilebilir (Dina vd. 1999:182). Kamu spotlarında, kazanç çerçeveli veya zarar çerçeveli tartışmaların ve duygusal çekiciliğin kullanılmasının, kamu spotlarının algılanan etkililiğini etkilediği düşünülmektedir (Keisler, 2016:102).

Günümüzde dijital iletişimin gelişimiyle birlikte kamu spotları, televizyon ve radyodan sonra internet üzerinden izlenebilir ve daha çok kitleye ulaşabilir hale gelmiştir. Bilişim teknolojilerinin gelişimi, kadın hareketlerinde internet teknolojilerinin kullanımını kolaylaştırmaya ve kadınların faydası için imkânlar oluşturmaya olanak sağlamıştır. Özellikle sosyal hareketlerin internet tabanlı yapılarla bağlantısı kadın hareketlerinde internetin önemini ortaya koymuştur (Terkan, 2010: 35). Diğer taraftan kadınların medyada yer alması konusunda toplumsal örgütlenme biçimi ve kültürel kodlar öne çıkmaktadır. Medyada kadına yönelik 
şiddetin sunumu, kadını ikinci plana atan, farklı kadın temsillerine yer açmayan cinsiyetçi tutum ve davranışların ortaya konduğu konulardandır (Atakul, 2002: 55). Ancak alternatif medya, egemen yapının yanında öteki olarak kurgulananların, kültürel olarak farklılaşan ve konumlandırılanların değer ve düşünce dünyalarının söylem alanlarına dönüştüğü ve bunlar üzerinden dolaşım sağlandığı bir yapıdır (Binark ve Gencel, 2007:186). Dolayısıyla bir yandan medya aracılığıyla kadını ikincilleştiren egemen söylemlere yer verilirken, alternatif medya gibi yeni alanlar kadın, çocuk, yaşlı, engelli gibi dezavantajlı grupların sorunları ve düşüncelerinin ifade edilmesine olanak sağlamaktadır.

Medya kampanyaları ve yasal düzenlemeler sayesinde bazı ülkelerde kadınlarla kız çocukları hakları konusunda insanlar daha bilinçli hale gelmekte ve tutumlar değişmektedir. Örneğin, Dünya Bankası verilerine göre, Nijerya'da kadınların \%44'ü 2003'te bir kocanın karısını dövmesinin olağan olduğunu söylemiştir ama on yıl sonra bu rakam $\% 21$ 'e düşmüştür. Benin'de aynı dönemde \%39'dan \%10'a düşüş yaşanmıştır; Haiti' de ise bu düşüşün \%11'den \%3'e düştüğü belirtilmiştir (akt. van Der Gaag, 2018:104).

Ülkemizde kadına şiddeti azaltmak ve toplumsal bir farkındalık oluşturma gibi çözümler üretmek amaciyla devlet kurumları ve kadın dernekleri tarafindan kamu spotları hazırlanmaktadır. 03/03/2011 tarihinde çıkarılan Radyo ve Televizyonların Kuruluş ve Yayın Hizmetleri hakkında Kanun, toplumsal cinsiyet eşitliğine aykırı, kadına baskı ve istismarı özendiren yayınlara karşı müeyyediler öngörmektedir. Radyo ve Televizyon Üst Kurulu (RTÜK)nun kendisinin cinsiyet eşitliği konularında broşür ve kamu spotu hazırlamadığ 1 fakat kamu kurum ve kuruluşları ve STK'larca hazırlanan toplumsal sorunlar, cinsiyet eşitsizliği vb. sorunların önlenmesi için yapılacak faaliyetlerde; özelliklerde bilgilendirici ve eğitici kamu spotları niteliğindeki filmlerin yayınlanmasında kamu yararı olduğuna dair karar yer almaktadır. Diğer taraftan Türkiye Büyük Millet Meclisi (TBMM) Kadın Erkek Fırsat Eşitliği Komisyonu tarafından 2012 yılında yayınlanan "Toplumsal Cinsiyet Eşitliğinde Medyanın Rolü” konulu komisyon raporunda, toplumsal cinsiyet eşitliği ve kadına yönelik şiddet konularında kamu spotu hazırlamak isteyen Sivil Toplum ve kamu kuruluşları arasında iş birliği kurulması, konuya ilişkin kamu spotlarının devamlı olarak yayınlanması önerilmiştir (TBMM, 2015:517). Bu filmlerin ulusal, bölgesel ve yerel medyada ulusal bir kampanya dahilinde gösterilmesine yönelik önerinin uygulaması için Kadının Statüsü Genel Müdürlüğü (KSGM) sorumlu kurum olarak belirlenmiştir. KSGM görev alanları itibariyle toplumsal alanda önemli olan tarihler 8 Mart, 25 Kasım ve 5 Aralık gibi günler için kamu spotları hazırlatılmaktadır. İlave olarak 2015 yılında, T.C. Aile ve Sosyal Politikalar Bakanlığı tarafından erken yaşta ve zorla yapılan evliliklerin önlenmesi için hazırlanan spot filmin "zorunlu yayın" olarak yayın kuruluşlarında yayınlanmasının önerilmesine karar verilmiştir (TBMM, 2015:754).

Türkiye'de kamu spotlarının durumunu tespit ve kamu spotlarının etkilerine yönelik nicel ve nitel yöntemlerle yapılan çalışmalar (Şeker ve Tiryaki, 2013; Yaman ve Göçkan, 2015) olmasına rağmen kamu spotlarının içeriklerine yönelik araştırmalar çok değildir. Bu bağlamda Türkiye'deki kamu spotlarını inceleyen "Türkiye'de Yayınlanmış Olan Kamu Spotlarının İçerik Analizi Yöntemi ile İncelenmesi” başlıklı çalışma dikkat çekmektedir (Özbük ve Öz, 2017). Kamu spotlarında işlenen metinlerin söylemleri, görsellerindeki örtük anlam, imalara ilişkin göstergebilimsel çözümlemeler sorunların çözümündeki etkinlik açısından önemlidir. Buna karşın Türkiye'de bu yönden bir çözümleme oldukça azdır. Türkiye'de emniyet, kültür ve sağlık temalı kamu spotlarına yönelik göstergebilimsel çalışmalar yakın zamanda gerçekleştirilmiştir. (Göçmen ve Ayvaz, 2017; Gülada, 2018; Tanca ve Ünal, 2018). Kadın sorunlarının çözümlenmesinde yapılan çalışmaların nicelliği kadar içeriğine yönelik inceleme de etkilidir. $\mathrm{Bu}$ bakımdan çalışma, Türkiye'de kadına yönelik şiddet temalı kamu spotunun göstergebilimsel çözümlemesi olması açısından önemli olduğu ve toplumda kadının konumu ve uğradığı şiddete yönelik diğer çalışmalara katkı sunacağı düşünülmektedir. 


\section{Kadına Yönelik Șiddet Türleri}

Şiddet ve şiddet türleri, uygulama açısından toplumsal farklılıklar gösterse de Birleşmiş Milletlerin (BM) Kadınlara Yönelik Şiddetin Önlenmesi Bildirgesi, kadınlara yönelik şiddeti; "İster kamusal isterse özel yaşamda meydana gelsin, kadınlara fiziksel, cinsel veya psikolojik acı veya 1stırap veren veya verebilecek olan cinsiyete dayanan bir eylem veya bu tür eylemlerle tehdit etme, zorlama veya keyfi olarak özgürlükten yoksun bırakma" (1. madde) şeklinde tanımlamaktadır (Canikoğlu, 2015: 359). Kadına şiddet denilince genelde ilk akla gelen fiziksel şiddettir. Oysaki şiddet olgusunun gelişen toplumsal yapılara göre tanımlara da sahip olduğu gözlenmektedir. Daha sonra, kadınların ekonomik ihtiyaçlarından yoksun bırakılması şiddet tanımlarına dahil edilmiştir. Bazı sosyo-kültürel faktörler de, şiddet oluşumuna etkendir. Aslında şiddet, kadın ve erkeğin toplumsal düzende eşit olmayışları ve iletişim eksikliği temelinden tartış1maktadır (Parmaksızoğlu, 2011: 12).

2012 yılında T.C. Aile ve Sosyal Politikalar Bakanlığı, Hacettepe Üniversitesi, Nüfus Etütleri Enstitüsü’nün “Türkiye'de Kadına Yönelik Aile İçi Şiddet” araştırmasında belirtilen şiddet tanımlamalarına bakıldığında erkekler (eş veya birlikte olunan) tarafından uygulanan fiziksel, duygusal ve ekonomik boyutuyla üç farklı şekilde ele alınmakta ve bu boyutların içerikleri tanımlanmaktadır. Eylem için kullanılan araçlara, ötekileştirmeye, toplumsal alan ve bireysel olarak yoksun bırakmaya kadar birçok nokta şiddet olgusu içerisinde ele alınmaktadır (Hacettepe, 2017: 52).

Kadının aile ve toplum içindeki tanımlamaları ve maruz kaldığ şiddet, toplumsal cinsiyet kavramı ile birlikte düşünülmelidir. Aile içinde erkeği üstünleştiren ve kadını baskılayan iktidar ilişkileri üzerine kurulu feminist teori, toplumsal cinsiyet temelinde ele alınmalıdır (Gödelek, 2005:102). Toplumsal cinsiyet kavramı, biyolojik özelliklerden farklı bir biçimde, kadın erkek ilişkilerinin toplumsal statü ve roller çerçevesinde sosyal ve kültürel kodlarla tanımlanması ve toplumun cinsiyetleri ayırt etme ölçütlerini açıklamak amacıyla kullanılır. Şiddetin ardında kadın erkek arasındaki güç ilişkileri, eşitsizlik, cinsiyet rolleri gibi sosyo-psikolojik ve kültürel etmenler vardır. Kazançlardaki eşitsizlikleri açıklamak; çocuk bakıcısı çalışanların neden otopark bekçilerinden daha az kazandıklarını ortaya koymak; kamu, bankacılık ve finans alanında kadınlardan ziyade erkeklerin iktidar konumlarında yoğunlaşmalarını açığa çıkarmak kısacası toplumsal cinsiyet ilişkileri, toplumsal cinsiyet eşitsizliği ve bunların bağlantılarının iktidarın bölüşülmesiyle olan ilişkilerini anlamak için psikolojik süreçlerin ötesindeki sosyal kalıplara ve sosyal düzenlemelere bakılmalıdır (Bilton vd., 2009: 137). Dolayısıyla, kadına şiddet, şiddetin arkasındaki unsurların ortaya çıkarılması ve bunlara yönelik çözüm yollarının araştırılması ile çözülebilir. Geçmişten günümüze kadın kimliğini ve kadına bakışı, algılar üzerinden değerlendirmek; kadına yönelik şiddet, sınırlamalar, kadın kimliği ve kadın algısı geleneksel ve modern yaşam standartlarında tekrar etmesi bu çıkarımı destekleyen göstergelerdir (Karatay, 2015: 23). Kamerun'da çekilen kadına şiddete yönelik çekilen kamu spotu filmi "My Voice | Short Film Against Gender-Based Violence" (Benim Sesim / Cinsiyet temelli Şiddete Karşı Kısa Film), şiddetin fiziksel, zihinsel, cinsel boyutlarına değinilerek farkındalık oluşturulmaya çalışılan filmlere bir örnektir. BM Mülteci Örgütü'nün 2016'da yaptığı şiddet araştırmasında, Kamerun'daki aile içi şiddet, fiziksel şiddet, psikolojik veya duygusal şiddet, cinsel şiddet ve ekonomik şiddeti kapsamaktadır. Görüşülen kadınlardan yaşamları boyunca, fiziksel şiddete uğrayanların oranı $\% 45$, cinsel şiddete uğrayanların oranı yüzde $\% 20$ ve arkadaş veya eşinden duygusal şiddet yaşayanların oranı ise \% 42 olarak belirtilmiştir (Refworld, 2016).

Kadının hane içinde eşitsiz durumu, emeklerinin karşılıksızlığı, toplumsal örgütlenme ve iktidar ilişkilerinin erkeğe sağladığı güç karşısında zayıflaşan kadının şiddete maruz kalmasına yol açmaktadır (Gödelek, 2005: 102). Mülkiyet ilişkileri ve maddi kaynakların kadın üzerinde belirleyici bir unsur olarak kullanılması şiddetin ekonomik tarafını kurumsallaştırmakta, kadının sosyalizasyon sürecinde geri planda birakılması, bireysel ve ekonomik özgürlüklerden yoksun 
olması, kadınların çocukluktan başlayarak çalışma hayatında daha az yer almalarına neden olmaktadır (Gökkaya, 2011:104).

Araştırmaların ortaya koyduğu önemli bir bulgu da, kadına yönelik şiddetin yoğun olduğu toplumların, kadınların statüsünün bir değişim süreci yaşadığı toplumlar olmasıdır. Kadının statüsünün çok aşağılarda olduğu toplumlarda, erkeğin otoritesini dayakla kabul ettirmesi zaten gerekmemektedir. Kadınların yüksek bir statü kazandığı toplumlarda da kadınlar kendi cinslerinin rolü konusunda geleneksel anlayışı yıkmaya yetecek gücü kollektif olarak ele geçirmiş olurlar. $\mathrm{Bu}$ durumda kadınlara yönelik şiddet en yoğun biçimde kendini kadınların geleneksel olmayan roller oynamaya ya da ücretli olarak çalışmaya başladıkları yerde ortaya çıkar (aktaran Baygal, 2016:188).

Şiddet sadece kadınların korkmasına sebep olmamakta, aynı zamanda toplumda eşit bir rol oynamalarına da engel olmaktadır. Dünyada kadına şiddet oranları fazla olmasına rağmen toplumsal cinsiyet alanında çalışanların ve kadın haklarını destekleyenlerin bazıları bu istatistiklerin "herkesin bildiği bir şey" olduğunu söyleyip bunları önemsememektedir. "Ev içi şiddet" ifadesi bir şekilde bunu olağanlaştırmakta ve "partner şiddeti" kulağa "emniyetli" ve "sınırlı" gelmektedir. Harekete geçmeye yol açan türden bir dikkat verilene kadar kadınlar ve kız çocukları kendi evlerinde, sokakta, işte veya korkmamaları gereken başka bir yerde güvende olmadıklarını hissetmeye devam edeceklerdir (Van Der Gaag, 2018:102). Şiddetle topyekûn bir mücadele için şiddeti tetikleyen geleneksel ve kültürel etmenlere dikkat edilmesi gerekmektedir.

\section{Dünya'da Kadına Şiddet}

2002-2006 yılları arasında Birleşmiş Milletler'in verilerine göre hayatlarında en az bir kere cinsel şiddete uğrayanların oranı, Meksika'da \%44, Çek Cumhuriyeti'nde \%35, Avusturalya'da \%34, Danimarka'da \%28, İsviçre'de \%25, Filipinlerde \%6, Fransa'da \%5 ve Azerbaycan' da \%4 olarak gerçekleşmiştir (Oktay, 2015: 76). Dünya Sağlık Örgütünün 2015 yılı raporuna göre ise, dünyada kadınların \%35'i eşli veya eşsiz fiziksel ve cinsel şiddete maruz kalmaktadır. Dünya genelinde her dört kadından 1'i ve her 6 erkekten 1'i yaşamlarının bir döneminde aile içi şiddete uğramaktadır. Dünya Sağlı Örgütü (DSÖ)'nün tahminlerine göre tüm dünyada üç kadından biri yaşamlarının bir döneminde dövülmekte, cinsel ilişkiye zorlanmakta ve diğer yollarla taciz edilmektedir. Tacizi yapan kişi genellikle kendi ailesinden biri ya da tanıdığı bir kişidir.

15 yaşından itibaren partner dışı kişilerden görülen fiziksel şiddet oranları incelendiğinde Türkiye'de \%14, İspanya'da \%14 ve İtalya'da \%16'dır. Partnerden görülen fiziksel şiddet oranları ise Türkiye'de \%36, İspanya'da \%12 ve İtalya'da \%17'dir. 15 yaşından itibaren partner dışı kişilerden görülen cinsel şiddet oranları incelendiğinde ise Türkiye'de $\% 3$, İspanya'da \%3 ve İtalya'da \%5'tir. Partnerden görülen cinsel şiddet oranları Türkiye'de $\% 12$, İspanya' da $\% 4$ ve İtalya' da \%7'dir. Ekonomik şiddet yüzdelerine bakıldığında Türkiye'de \%30, İspanya'da \%8 ve İtalya'da \%13'tür (Palmen, aktaran Uyar vd., 2018: 160).

\section{Türkiye'de Kadına Şiddet}

Türkiye İstatistik Kurumu'nun (TÜİK) 2008 yılında yapmış olduğu araştırma Türkiye'de Kadına Yönelik Aile İçi Şiddet 'in verilerinden hareketle yapılan araştırma sonuçlarına göre, kadına yönelik şiddet olgusunda iki nokta ortaya çıkmakta ve bunların başında kadının sosyoekonomik ve psikolojik durumu gelmektedir. İkinci nokta ise şiddeti algılama ve yorumlama biçimidir. Buradan hareketle algılama ve yorumlama perspektifinden kadına yönelik şiddetin önlenmesinde, toplumsal farkındalığın önemi ortaya çıkmaktadır (Çalışkan ve Çevik, 2018: 218).

Ülkemizde yaşanan aile içi şiddetin nedenleri arasında evlilik yaşamındaki tatminsizlikler, bireylerin şiddet eğilimli olması, eşler arasındaki eğitim ve statü farklılıkları, iletişim bozuklukları, evliliğe yönelik aşırı bağımlılık sayılabilir. Türkiye'de önemli bir oranda yaşanan, aile içi şiddet sorunu ülkemizde, 1980'lerden itibaren tartışılmaya başlanmıştır. Liberal 
toplumsal yapı ve toplumsal alanda farklı olguların da tartışmaya katılması ile birlikte 1980'lerin ikinci yarısı kadın hareketlerinin örgütlü ve bağımsız eylemler olarak çoğaldığ bir dönemdir. Birleşmiş Milletler Genel Kurulu'nda 1979'da Kadına Karşı Her Türlü Ayrımcılığın Önlenmesi Sözleşmesi'nin kabul edilip 1981'de yürürlüğe girmesi ve sözleşmenin Türkiye tarafından 1985 yılında imzalanması, kadın hareketlerine hız kazandırmıştır. Çok geçmeden 17 Mayıs 1987 tarihli Dayağa Hayır Yürüyüşü, şiddete karşı kadınların ilk toplu eylemi olarak kayıtlara geçmiştir (Kocacık, 2004: 42). Bu yürüyüşten sonra yazılı basın anlamında aile içi şiddete karşı çeşitli kitaplar yayımlanmaya başlanmıştır. Sivil alanda toplumsal örgütlenmeler de bu bağlamda yavaş yavaş ortaya çıkmıştır. Mor Çatı Kadın Sığınağı Vakfı 1990 yılında kurulmuş ve Vakıf, şiddete uğrayan kadınlara sığınma ve rehberlik sağlamaya bugün de devam etmektedir (MORÇATI, 2018). Gelişen zaman diliminde farklı toplumsal ve siyasal tabakaların da dâhil olduğu kadın örgütlenmeleri toplumda çoğalmıştır. 2013 yılında kurulan Kadın ve Demokrasi Derneği (KADEM), kadını güçlendirmek ve kadına yönelik şiddeti önlemek adına çalışmalarını sürdürmektedir (KADEM, 2018).

Türkiye'de aile içi şiddetle ilgili genel görünüm şöyle özetlenebilir; Kadınlar dayak olayını ailevi bir sorun olarak görmektedir ve şikâyette bulundukları zaman şiddete uğramaktan korkmaktadır. Toplumsal ötekileştirme, yalnızlaşma ve can güvenliği gibi korkular kadının susmasında başlıca etmenlerdendir (Yanık, aktaran Çalışkan, Çevik: 2018: 220). Kadınlarda şiddet sonucunda çeşitli psikolojik ve psikiyatrik rahatsızlıklar ortaya çıkmaktadır (Köse ve Beşer, 2007:118). Ülkemizde, aile içi şiddet yoğun olarak görülmektedir. Türk aile yapısının temel özellikleri nedeniyle cinsiyet ayrımcıllğ 1 ve toplumsal alana katılamama sorunu birçok mağduriyetin temelini oluşturmaktadır (Aksu ve Üstün, 2005: 18). 2015 yılında yapılan Türkiye'de Kadına Yönelik Aile İçi Şiddet Araştırması'nda, kadınların yüzde 36'sının fiziksel, yüzde 12'sinin cinsel, yüzde 38'inin iki şiddet biçiminden en az birine maruz kaldığ fiziksel şiddet ile cinsel şiddetin bir arada olduğunu göstermektedir. En yaygin şiddet biçimi olan duygusal şiddet/istismar açısından, evli kadınların yüzde 44'ünün, duygusal şiddetin en az birine hayatının herhangi bir aşamasında uğradığını ortaya koymaktadır (Hacettepe, 2015:83,92).

2017 yılında Ayşe Ediz ve Şenol Altan tarafından yapılan “Türkiye’de Kadına Yönelik Şiddet Üzerine Alan Araştırması"na göre, her eğitim seviyesinden kadınlar şiddete maruz kalmışlardır. Kadının geliri ile şiddet arasında ters bir orantı tespit edilmiş̧ir. Gelir seviyesi arttıkça şiddet oranı da azalmaktadır. Kadınların kamu kuruluşlarından beklentileri sorulduğunda, kadınlar, mevcut statülerinin yükseltilmesi için eğitim alanında pozitif ayrımcılık sağlanması, daha sonraki aşamada ise ekonomik şartların iyileştirilmesini istediklerini belirtmişlerdir (Ediz ve Altan, 2017: 403). Diğer taraftan medya üzerinden yapılan bir araştırma (Bianet, 2018) sonucuna göre 2018 yılının ilk 10 ayında en az 203 kadın, erkekler tarafından uygulanan şiddet sonucunda hayatını kaybetmiştir².

\section{Film Çözümlemelerinde Anlatı Kodları}

Göstergebilim, çevremizdeki dizgelerin nasıl ve niçin oluştuğunu incelerken, farklı yaşam alanlarındaki sorunlarla nasıl baş ettiğimizi ve dünyayla baş etme yöntemlerimizin aynı olup olmadığını araştıran bir inceleme yöntemidir (Akerson, 2005: 14). Göstergebilim çözümlemeleri, göstergeler yoluyla iletilen mesaj ve anlamlara yöneliktir. Bir nevi kod açımıdır. Kodlar toplum içerisinde belirlenmişlerdir ve göstergelerin anlamlarıdır. Anlamlar sosyo-kültürel olup toplumdan topluma değişebilmektedir. "Gösterilen", zihnimizde oluşturulan soyut bir kavram yapıya gönderme yapar. Bu yapının ifade edildiği somutlaşmış nesneye "gösteren" adı verilir (Güngör, 2011:185).

Anlatılar hem söylem çözümlemelerinin hem göstergebilimin inceleme alanına giren söylem türleridir. Anlatıların çözümlenmesi ise yalnızca anlamı değil, anlamla birlikte anlatı yapısını, ideolojik bağlamın anlatıları nasıl etkilediği ve yüklemeler yaptığını da analiz

${ }^{2}$ Aktaran https://www.dw.com/tr/verilerle-t\%C3\%BCrkiyede-kad\%C4\%B1na-\%C5\%9Fiddetin-anatomisi/a-46440667 
etmektedir. Anlatı çözümlemeleri iki kaynak üzerinden inşa edilmektedir. Örneğin Maupassant (1976) kitabında Greimas, metnin iç düzenlemesini iki kısımda çözümlemektedir. Bunlar Dizisel Çözümleme (Paradigmatik Çözümleme) ve Dizimsel Çözümleme (Sentagmatik Çözümleme) dir:

1. Dizimsel Çözümleme (Sentagmatik Çözümleme): Bu çözümlemede metinde bir anlatıyı oluşturan olaylar zincirinin segmentleri üzerinde durulmaktadır.

2. Dizisel Çözümleme (Paradigmatik Çözümleme): Metnin içinde gömülü ve metne anlamı veren zitlıklar üzerinde durulmaktadır (Greimas, 1988: 27).

Anlatıların ilk çözümleme yöntemini geliştiren Propp (1985), Rus Halk masallarında ortak yapı birimlerini, karakterlerini ortaya koymuştur. Yüzlerce masalın çözümlemesini yaparken tümünde benzer bir anlatı yapısı belirlemiştir. Masalların dizisel çözümlemesinde hiç değişmeyen 31 işlev belirlemiştir. Propp'un geliştirdiği anlatı yapısı, medya metinlerinin çözümlerinde de kullanılmaktadır.

Tablo 1. Propp'un belirlediği masal kahramanları

\begin{tabular}{ll}
\hline Anlatılarda Karakter Roller & Hareket Alanları \\
\hline Saldırgan: & Kötülük, çatışma, kavga, izleme \\
\hline Bağışçı: & $\begin{array}{l}\text { Büyülü nesnenin kahramana verilmesi, büyülü nesneyi } \\
\text { ulaştırmaya hazırlık }\end{array}$ \\
\hline Yardımc1: & $\begin{array}{l}\text { Kahramanın uzam olarak yer değiştirmesi, Kötülüğün } \\
\text { giderilmesi. İzlemeye yardım. Güç görevleri halletme. } \\
\text { Kahramanın biçim değiştirmesi. }\end{array}$ \\
\hline Prenses ve babası: & $\begin{array}{l}\text { Düzmece kahramanın ortaya çıkarılması, gerçek kahramanın } \\
\text { tanınması, düzmece kahramanın cezalandırılması }\end{array}$ \\
\hline Gönderen: & Kahramanı gönderir. \\
\hline Kahraman: & Arayış için yola çıkar. \\
\hline
\end{tabular}

Kaynak: Propp, 1985:83

Saldırganın işlevlerini biraz daha açmak gerekirse, saldırgan aileden birine zarar verir, kişilerin bedenlerine zarar verir, kurbanını bir şey yapmaya zorlar ya da zorla ondan birşey koparır, saldırgan birini öldürür, birini bir yere kapatır veya hapseder, saldırgan her gece birine zarar verir (Propp, 1985: 41).

Anlatı çözümlemelerinde, Greimas'ın, Propp'tan etkilenerek ortaya koyduğu Eyleyenler Modeli öne çıkmaktadır. Eyleyenler modelinde metinde anlamının nasıl oluştuğunu, metnin yüzeyinden derin düzeyine doğru nasıl bir yol izlenerek ortaya konduğunu açıklamaya çalışmaktadır. Modelde, her metinde anlatıyı oluşturan altı eyleyen bulunur. Bunlar; Özne, Nesne, Gönderen, Gönderilen, Yardımcı ve Engelleyicidir. Eyleyenler genellikle insan, ancak bazı anlatılarda toplumsal sıfatlar üzerinde temellendirilir. Anlatılarda gönderici iken özne, yardımcı iken engelleyici duruma geçmesi olasıdır. Diğer taraftan birden fazla özne bir eyleyensel rol üstlenebilir. Böylece, örneğin engelleyici işlevi bir grup tarafından gerçekleştirilebilir. Böyle kişilere ortak eyleyen denilir (Kıran, 2011:272).

Greimas kişiyi ne olduğu ile değil ne yaptığı ile değerlendirmektedir. Bu model altı eyleyen kategoriyi ikişerli gruplar halinde kendi arasında bir araya getirir.

Eyleyenler Modeli'ni eksen ve eyleyenler açısından açıklamak gerekirse (Kıran, 2011:273-284);

1- İsteyim Ekseninde Özne ile Nesne Arasındaki İlişki: Özne temelde kritik eylemlerde yer alan belirleyici unsurdur. Nesne ise, kahramanın ulaşmak istediği soyut ya da somut kişi veya nesnedir. Özne ve nesnenin rolleri birbirlerine göre tanımlanır: Nesnesi olmayan özne, öznesi olmayan nesne düşünülemez. Nesne rolünü bazen insan, bazen ahlaki bir değer üstlenebilir. 
2- İletişim Ekseninde Gönderici ile Alıcı Arasındaki İlişki: Gönderici açısından, özne eksik olanı arar, sonucunda ya ödül ya da ceza vardır. Ancak bazen özne kendi arzusu ile eylemde bulunur. Eyleminin sonucunda kendini ödüllendirdiği gibi cezalandırabilir.

3- Güç Ekseninde Yardımcı ile Engelleyici Arasındaki İlişki: Anlatıda öznenin eylemini kolaylaştıran yardımcılar ile onun amacına erişmesini engelleyenler olabilir. Bazen sadece yardımcı ya da engelleyici bulunabilir, bazen de hiçbiri. Bu roller bazen cansız varlıklarca gerçekleştirilebilir. Bir hastalık, savaş engelleyici eyleyen olabilir, bir köprü bir bilgi yardımcı işlevi yüklenebilir.

Bir anlatıyı Greimas'ın Yapısalcı Anlatı göstergebilim yöntemi ile çözümleyebilmek için öncelikle anlatım düzlemini sonrasında içerik düzlemini anlamalıyız. Anlatıların sözdizimsel boyutu, metinlerin olay örgüsüyle, arka planıyla ya da başka bir deyişle kurgusu ile ilgilidir. Bir anlatının oluşması bir başlangıç ve sonuç (durum sözcesi) durumu gerektirir. Anlatı durumu dört evreden oluşmaktadır: Eyletim, Edinim, Edim, Yaptırım (Rıfat, 2011: 41). Greimas, yorumlarından en önemlisini, üçüncü boyut üzerine getirir. $\mathrm{Bu}$, temel anlamsal boyut düzlemidir. Bu boyut, diğer iki boyutun gerisinde yer alan derin anlama tekabül eder (akt. Soydan, 2007: 8).

Dolayısıyla önce metni kesitlere ayırarak kişilerin nasıl konumlandırıldığını belirleyerek söylemsel düzeye ulaşmalıyız. Eyleyenlerin metin içerisinde konumlandırılmasını kavrayarak anlatı düzeyine geçeriz. Söylem ve anlam düzeylerinde asıl verilmek istenen mesaj, gizli anlam, imaları meydana çıkararak temel yapı düzeyine ulaşırız.

\section{Anlatı Durumunun Evreleri:}

Anlatı Durumu'nun Birinci Evresi: Eyletim (Manipülasyon): Bir anlatı öznenin aranıp bulunmasıyla oluşmaya başlar. Bir eyleyen (İnsan, hayvan, nesne bağlamında özne), bir başka eyleyen tarafindan bir eylemi yapmaya görevlendirilir ya da kendi kendine eylem yapmayı üstlenir. Eyletim, gönderen ile özne arasında gerçekleşen ilişkidir. Gönderen, özneyi ikna etmek ve etkilemek için belli bir izlenceyi takip eder, özne durumu değerlendirerek, uzlaşmayı kabul edip etmemeye karar verir. Göndericinin özneyi manipüle etmeyi başarmasıyla anlatı başlamış olur.

Anlatı Durumu'nun İkinci Evresi: Edinim (Yeterlilik, Güçlenme): Öznenin eylemi gerçekleştirebilmesi, doğuştan olan ya da sonradan kazandığı yeteneklerine bağlıdır. Bu yüzden bu evreye edinim denir. Bu evrede gönderenin işlevi sonlanır. Özne gerekli özellikleri bazı denemelerden sonra edinebilir. Öznenin eylemlerin akışını etkileyecek temel atılımları, yeteneklerine bağlıdır. Bu yeteneklerin yetersiz olması öznenin başarısızlığına neden olur. Özne gerekli yetenekleri kazanırken, yardım edenlerden destek görür, karşı-özneler ya da karşı çıkanlar tarafindan engellenir.

Anlatı Durumu'nun Üçüncü Evresi: Edim (gösterme): Özne gerekli yetenekleri edinince asıl eyleme geçer. Bu edimdir. Öznenin gereken eylemi gerçekleştirmesi, nesnesine ulaşmasıyla sonuca varılır.

Anlatı Durumu'nun Dördüncü Evresi: Yapttrım (teyit etme): Bu evre, öznenin yaptıklarının kendisini görevlendiren tarafından değerlendirildiği; ödüllendirildiği ya da cezalandırıldığı evredir. Kısacası, sonuç ve yapılanların değerlendirildiği evredir (Rıfat, 2011: 42).

\section{Yöntem}

Kamu faydası düşünülerek toplumu ilgilendiren birçok sorun ile ilgili olarak hazırlanan kamu spotlarının içeriklerinin ardındaki bilişsel algıya yönelik çözümleme önemli bir konudur. Bu amaçla, çalışmada devlet kurumları ve kadın dernekleri tarafından hazırlanan kamu spotlarının göstergebilimsel çözümlemesi yapılmıştır. Çalışmanın örneklemini T.C. Aile ve Sosyal Politikalar Bakanlığının "Kadına şiddet insanlığa ihanettir!" kamu spotu (2017), KADEM'in "Cins var, cins var" (2017) ile "Hangi yüzle" (2017) kamu spotu oluşturmaktadır. 
Kamu spotları, Greimas'ın Yapısalcı Anlatı göstergebilim yöntemi ile çözümlenmiştir. Dizimsel çözümlemede kamu spotları öncelikle evrelere (Eyletim, Edinim, Edim, Yaptırım) ayrılmıştır. Anlatıların başlangıçtan sonuca doğru aşamaları incelenmiştir. Eyleyenler ve işlevleri belirtilmiştir. Son olarak da dizisel çözümlemede metne anlamı veren zitlıklar üzerinde durularak söylem ve anlam düzeyinde verilmek istenen mesaj ortaya çıkarılmıştır.

\section{Bulgular ve Yorum}

\section{1. "Kadına Şiddet İnsanlığa İhanettir" İsimli Kamu Spotunun Göstergebilimsel Çözümlemesi}

24 Kasım 2017 tarihli kamu spotunun anlatım düzleminde, anlatının metni üreten öznesi T.C. Aile ve Sosyal Politikalar Bakanlığı'dır. Metni üreten, sözceleme öznesi olan Bakanlık, Ö1'dir. Karadenizli Erkek, Ö2'dir. Propp'un anlat1 şemasına göre burada özne yani kahraman ve yardımcılar, tek bir eyleyensel rol üstlenmiş̧lerdir. Dolayısıyla "ortak eyleyenler"dir.

\subsection{1. “Kadına Şiddet İnsanlı̆̆a İhanettir” İsimli Kamu Spotunun Dizimsel Çözümlemesi}

Anlatı durumu:

1. Evre: Film, Karadeniz türküsü sessel göstergesi ve tarihi köprü görüntüsüyle başlamaktadır. Köprünün üzerinde genç bir kadın arkası dönük olarak nehire bakmaktadır. Daha sonra kol kola girerek patikadan yürüyen yaşlı bir Karadenizli çift görüntüsel göstereni verilmektedir. Diğer kesitte, yan yana otururken gösterilmektedir. Erkek olan (Ö2) "Bizde şiddet yok, horon vardır" dilsel göstergesiyle Karadeniz insanının şiddete karşı olduğunu dile getirmektedir. Gösterilen, şiddet karşıtlığıdır. Filmde kadın sessizdir. Görüntü başladıktan sonra yeşillikler arasından geçen bir nehir üzerinde bulunan bir köprünün üzerinde duran bir kadın görülmektedir (Görsel 1, Görsel 2, Görsel 3, Görsel 4).

2. Evre ve 3. Evre: Bu evrede Karadenizli yaşlı adamın görüşleri güçlendirilmekte ve desteklenmektedir. Karadenizli adamın işlevi bu bölümde sona ermiştir. Yardımcılar bu evrede konu edilmiştir. Koyunlarını güden bir Yörük çobanın, sözleriyle Yörük kültürünün özellikleri aktarılmaktadır. Yörük olduğu görüntüsel gösterenlerin yanı sıra sessel gösterge olarak çobanın "Bizim özümüzde, kökümüzde, Yörüklükte kadına şiddete yer yoktur." söyleminden anlaşılmaktadır. Burada yine bir erkeğin sesinden bir yörenin şiddet konusuyla ilgili özellikleri dile getirilmiştir. Gösterilen, şiddet karşıtlığıdır. Kadın görsellerde yoktur. Daha sonraki evreler de birinci evredeki söylemi desteklemektedir. Doğulu yaşlı bir adamın sözlerine yer verilmiştir. Yöre kıyafetleriyle (gösteren) Şanlı Urfalı (gösterilen) olduğu görülen adam "Kadın topraktır, anadır" diyerek kadınlara annelik özelliğinden dolayı bir kutsallık ithaf etmektedir. Diğer evrede Ege, Marmara ve Akdeniz yöresine ait olduğu anlaşılan görüntüler yer almaktadır. Bu bölgeler, zeytin ağaçları gösterenleri ile anlatılmıştır. Burada, kadınla erkeğin işbirliğine vurgu yapılmaktadır. Zeytinlikte kadın ve erkeğin birlikte hasat yaptığı görüntüsel göstergede erkek, "İnsan gönlünü açtı̆̆ bir kişiye şiddet uygulayamaz" sözünü söylemektedir. Bu dilsel gösterge ile sevginin olduğu yerde şiddetin olamayacağ kenti göstergesinde bir iş adamı gösterilmektedir. İş adamı "Kadına yönelik her tür şiddetin karşısındayız" dilsel göstergesiyle, fiziksel, psikolojik her türlü şiddeti reddettiğini dile getirmektedir. Filmde birbirine bağlanan 5 farklı kesit ve 5 farklı bölgeden erkeklerin kadınlara farklı değerler üzerinden anlam yükledikleri ve dilsel göstergeler yoluyla şiddete karşı oldukları (gösterilen) aktarılmıştır (Görsel 5-15). Özne ve yardımcıların gereken eylemi gerçekleştirmesi, nesnesine ulaşmasıyla sonuca varılır. Burada nesne, soyut kavramlardır: paylaşım, iyi töreler, kadına değer, gönül birliğii, dayanışma, şiddet karşıtlığı, ortak değerler.

4. Evre : Eylemlerin değerlendirildiği en son evrede, bütün bu farklı değerlerin Türkiye halkının ortak değerleri olduğu ve hiçbir bölgemizde şiddete yer olmadığı değerlendirilmesi yapılmaktadır. "Bizi biz yapan ortak değerlerimizde şiddete yer yoktur" dilsel göstergesi ile ortak 
bir sonuca varılmaktadır. Metnin sözceleme öznesi logosu ve dilsel gösterge ile en sonda gösterilmektedir. Ayrıca kadına şiddetin sembolü olarak, beyaz bir zemin üzerinde avucu ve parmakları gözükecek şekilde koyu renkli bir el görülmektedir. Koyu renk kötülüğü, kirliliği beyaz renk temizliği ve iyiliği simgelemektedir (Görsel 13-16).

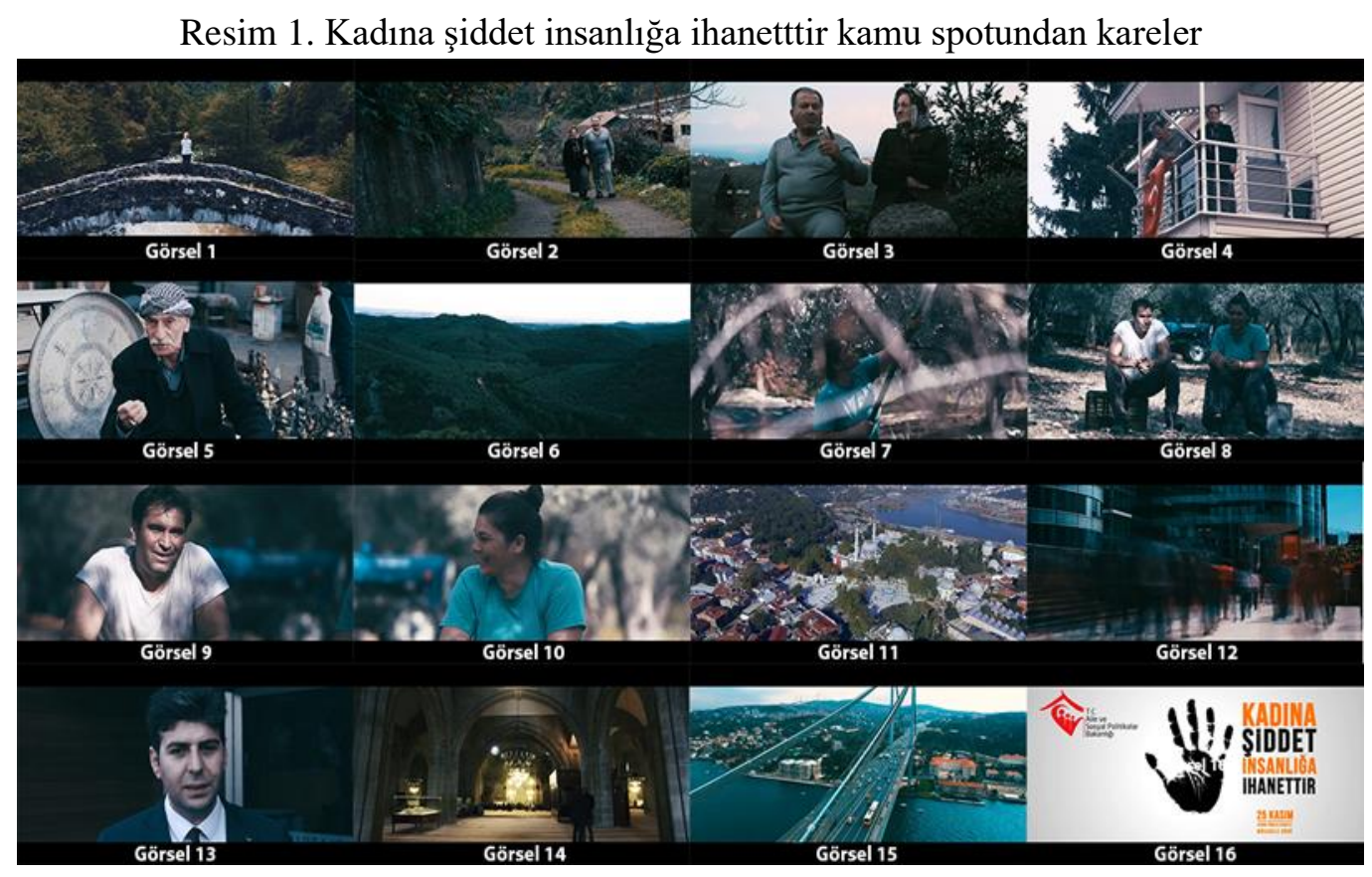

Tablo 2. Eyleyenler ve eyleyensel işlevler

\begin{tabular}{lll}
\hline Eyleyenler & & Eyleyensel İşlevler \\
\hline Gönderen & Karadenizli erkek & Eylemi belirleyen kişi \\
Nesne & $\begin{array}{l}\text { Paylaşım, iyi töreler, kadına } \\
\text { değer, gönül birliği, dayanışma, } \\
\text { şiddet karşıtlı̆̆ı, ortak değerler }\end{array}$ & \\
Karadenizli erkek & $\begin{array}{l}\text { Eylemin konusu kendisi için gerçekleştiği } \\
\text { kişi }\end{array}$ \\
Gönderilen & Karadenizli erkek & Eylemi yapar \\
Özne & Yok & Eylemi engeller \\
Engelleyici & Yörük Erkek, Doğulu Erkek, & Eyleme yardım eder \\
Yardımcı & Akdeniz Erkeği, Egeli Erkek, & \\
& Kent erkeği & \\
\hline
\end{tabular}

\subsection{2. “Kadına Şiddet İnsanlığa İhanettir” İsimli Kamu Spotunun Dizisel Çözümlemesi}

Eşiyle horon tepen Karadenizli (Ö2), kültüründe şiddet olmayan Yörük, analık özelliğinden kadına değer veren Doğulu, kadın ve erkeğin iş birliği ve gönül birliğine inanan Egeli/Akdenizli, şiddetin birçok türü olduğunu söyleyen kentli erkek, şiddete karşıdır. Bunların tersine inanan ve uygulayan şiddet yanlısıdır (Tablo 3).

Tablo 3. Kamu spotundaki karşıtlıklar

\begin{tabular}{ll}
\hline Karşıtlıklar & \\
\hline Kadınla hayatı paylaşır (Özne2) & Kadına şiddet uygular (Karşı Özne) \\
Değerlerine sahip çıar (Yardımc1) & Değerlerini dikkate almaz (Engelleyici) \\
$\begin{array}{l}\text { Gönlünü açtığı kişiye şiddet } \\
\text { uygulamaz (Yardımcı) }\end{array}$ & $\begin{array}{l}\text { Gönlünü açtğı kişiye şiddet uygulayabilir } \\
\text { (Engelleyici) }\end{array}$ \\
$\begin{array}{lll}\text { Kadına yönelik her tür şiddetin } \\
\text { karşıındadır (Yardımcı) }\end{array}$ & Kadına yönelik her tür şiddeti destekler (Engelleyici) \\
\hline
\end{tabular}




\section{Yorum}

Kamu spotunda her ne kadar paylaşma, iyi töreler, kadına değer, gönül birliği, dayanışma, şiddet karşıtllğ gibi unsurların Türkiye halkının ortak değerleri olduğu ve bu değerlerde şiddete yer olmadığ1 vurgulansa da ülkemizin her bölgesinde şiddetin görülmesi ve devam etmesi nedeniyle gerçeği yansıtmamaktadır. Ülkemizde iyi töreler olsa da namus cinayetleri gibi kötü törelerimiz de vardır. Şiddete yönelik istatistikler bunun en önemli göstergesidir. Ayrıca filmde konuşan erkeklerdir. Kadınlar ise sessiz ve uyumlu bir görüntü vermektedir. Filmde erkekle birlikte kadının da konuşması kadın-erkek güç ilişkileri açısından kamuya daha etkili bir mesaj verilebilirdi. Kadının buradaki edilgen erkeğin etken pozisyonda yer alması, kadının erkeğe itaatine dayalı feodal yapıyı normalleştirmektedir.

\section{2. “Cins var, Cins var -2-" İsimli Kamu Spotunun Göstergebilimsel Çözümlemesi}

25 Kasım 2017 tarihli “Cins var, cins var-2-" isimli kamu spotu, KADEM'in kadına karş1 şiddet temalı olarak çekilen "Cins var, Cins var" adlı serinin ikincisidir. Kamu spotunun anlatım düzleminde, anlatının metni üreten öznesi ve sözceleme öznesi KADEM'dir. Sözcenin üretim zamanı 25 Kasım 2017, uzamı ormandır. KADEM incelemenin tamamında Ö1 olarak anılacaktır. İkinci özne ise kurttur. Saussure'ün gösteren-gösterilen ilişkisine göre kurt gösteren, kadına şiddet uygulamayan erkek gösterilendir ve simgedir. Kurt çözümlemede, Ö2 olarak anılacaktır. Dişi Kurt Ö3'tür. Kadına şiddet uygulayan erkek ise karşı özne olarak anılacaktır. Videoda görsel, dilsel ve işitsel öğeler anlamlı bir bütün oluşturacak şekilde kullanılmıştır. Tüm öğeler eş zamanlı bir şekilde kullanılmıştır. Ancak görsel öğeler Ö2 nin konumlandırılması nedeniyle daha baskın hale gelmiştir.

\subsubsection{Cins var, Cins var 2" İsimli Kamu Spotunun Dizimsel Çözümlemesi}

\section{Anlatı durumu:}

1. Evre: Eyletim (Gönderme): Kamu spotu, karlarla kaplı ormanda güneşin doğuşu ile başlamaktadır. $\mathrm{Bu}$ zamansal olarak günün ilk başlangıcını göstermektedir. Günün başından sonuna doğru hiçbir evrenin atlatılmadan kurtun davranışlarının verileceği ve öne sürülen düşüncenin de ön kanıtı niteliği taşımaktadır. Daha sonrasında kurtun sessel göstereni ile hikâye başlar. Gösterilen kurtun ürkütücü sesdir. Kurt içgüdüsel olarak kendi kendini görevlendirmiştir (Görsel 1, Görsel 2).

2. Evre: Edinim (Yeterlilik, Güçlenme): Burada, dilsel gösterge ile kurt metaforunun güçlü özelliklerine yer verilmektedir: "Kurt, 200 milyon koku alma hücresine sahiptir. Ürkütücü sesi 16 km'den duyulmaktadır. 750 kg çene basıncına sahiptir." Gösterilen, Ö2'nin biyolojik olarak güçlü özellikte olduğudur. Yırtıcı ve vahşi bir hayvan olan Ö2'nin görüntüsel göstergesinin kullanılmasıyla ürkütücü betimlemesi pekiştirilmektedir. Filmde soğuk renkler olarak mavi ve gri tonlarının kullanılması korku algısını vurgulamaktadır (Görsel 3).

3. Evre: Edim (gösterme): Dilsel gösterge: "Ailesine düşkün olan kurt, eşinin yavrularının ve grubunun güvende olmasını ve aç kalmamasını sağlar”. Bu kesitte Ö1'in aktardığı dilsel göstergede gösterilen, Ö2 nin sosyal ve koruyucu bir hayvan olduğu, aile ve grubuna önem verdiği, aile ve sahiplenme duygusu gelişmiş bir hayvan olduğudur (Görsel 4).

4. Evre: Yaptırım (teyit etme): Dilsel gösterge: "Anadolu'da geleneksel adı "canavar" olan kurt eşine asla saldırmaz.” Burada Ö2'nin yörede "canavar" olarak adlandırılması eleştirilmiştir. Eşine saldırmayan Ö2'nin canavar imgelemiyle anılması tezatlık teşkil etmektedir. Burada asıl canavarın eşine saldıran insanların olduklarına dair alt mesajı da verilmektedir. "Bazı cinslerin, diğer cinslerden öğreneceği çok şey var" dilsel göstergesinde bazı cinsler gösteren, erkekler gösterilen, diğer cinsler gösteren, hayvanlar gösterilendir. Söylemin düz anlamı, bazı cinslerin diğer cinslerden öğreneceği çok şey olduğudur. Yan anlam ise, hayvanlardan üstün kabul edilen insanların da bazen hayvanlara göre kusurlu olabileceği ve davranışlarında yanlışlıklar 
olduğu, şiddet uygulamama konusunda hayvanlardan örnek alması gerektiğidir. Filmde ödüllendirme yoktur, ödüllendirme yerine kurtun davranışları dilsel göstergeler aracılı̆̆ııla desteklenmektedir, karşı özne olan şiddet uygulayan erkek (insan) uyarılmaktadır (Görsel 5, Görsel 6, Görsel 7, Görsel 8, Görsel 9).

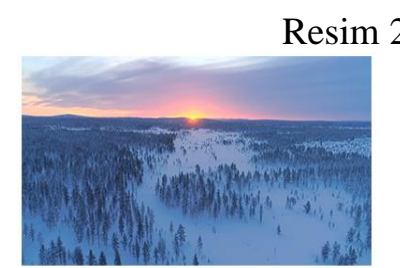

Görsel 1

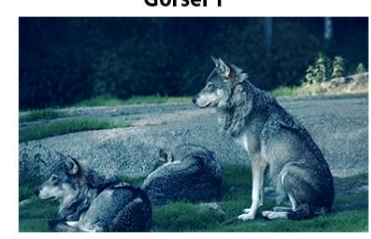

Görsel 4

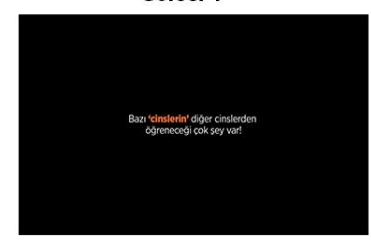

Görsel 7

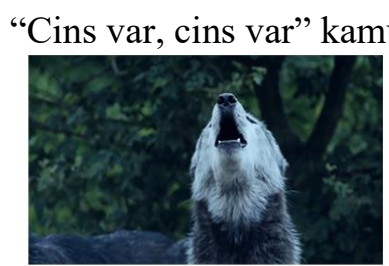

Görsel 2

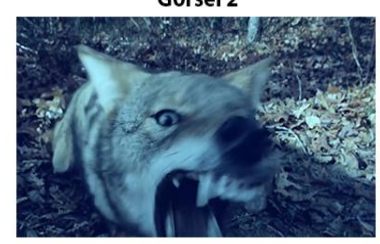

Görsel 5

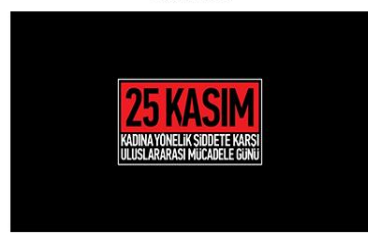

Görsel 8
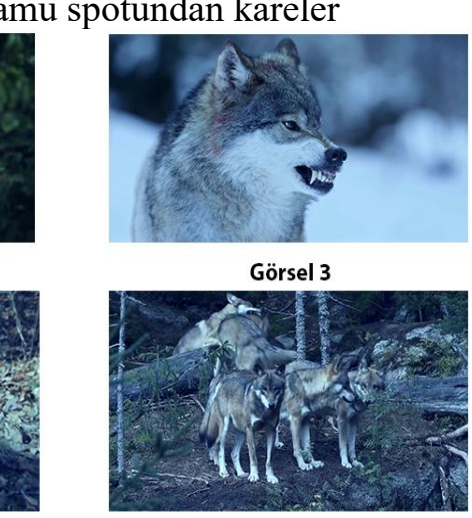

Görsel 6

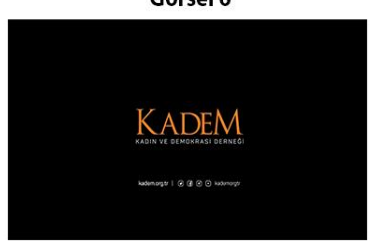

Görsel 9

Tablo 4. Eyleyenler ve eyleyensel işlevler

\begin{tabular}{lll}
\hline Eyleyenler & & Eyleyensel İşlevler \\
\hline Gönderen & $\begin{array}{l}\text { Kurtlar kendi kendini görevlendirir, } \\
\text { içgüdü }\end{array}$ & Eylemi belirleyen kişi \\
Nesne & Aile duygusu & Eylemin konusu \\
Gönderilen & Erkek Kurt ve Dişi Kurt & $\begin{array}{l}\text { Eylemin kendisi için gerçekleştiği } \\
\text { kişi }\end{array}$ \\
Özne & Dişi Kurt, Erkek Kurt & Eylemi yapar \\
Engelleyici & $\begin{array}{l}\text { Diş tehditler } \\
\text { Yrkek Kurt, Aile, sahiplenme } \\
\text { Yardımcı }\end{array}$ & Eylemi engeller \\
& Eyleme yardım eder \\
\hline
\end{tabular}

\subsection{2. “Cins var, Cins var 2" Isimli Kamu Spotunun Dizisel Çözümlemesi}

Kadına yönelik şiddetle mücadele günü kapsamında hazırlanan kamu spotunda kurt metaforu kullanılarak, erkeklerin kadına şiddeti eleştirilmiştir. Filmde "Erkeklerin kadınlara uyguladığı şiddeti yırtıcı hayvanlar bile eşlerine uygulamıyor ve bu konuda erkeklerin hayvanlardan öğreneceği çok şey var" üst metni işlenmektedir. Kamu spotunda karşıtlıklar şiddet ve şevkat üzerinden kurulmuştur. Gücü kötü kullanan, hassas olmayan, ürkütücü olan, ailesini korumayan, eşine saldıran erkek (insan cinsi) dir. Gücünün farkında olan, hassas olan, sevecen, eşini ve ailesini koruyan, eşine saldırmayan metafor olarak erkek kurt (hayvan cinsi) tur (Tablo 5).

Tablo 5. Kamu spotundaki karşıtlıklar

\begin{tabular}{lll}
\hline Karşıtlıklar & \\
\hline Gücü kötü kullanan (Ö4) & Gücünün farkı̈da olan (Ö2) \\
Hassas olmayan (Ö4) & Hassas olan (Ö2) \\
Ürkütücü (Ö4) & Sevecen (Ö2) \\
Ailesini korumayan (Ö4) & Eşini ve ailesini koruyan(Ö2) \\
Ailesinin güvenliğini ve & bakımın1 & Ailesinin güvenliğini ve bakımı \\
sağlamayan (Ö4) & sağlayan (Ö2) & \\
Eşine saldıran (Ö4) & Eşine saldırmayan (Ö2) & \\
Canavar olan (Ö4) & Canavar olmayan (Ö2) \\
\hline
\end{tabular}




\section{Yorum}

Bu kamu spotunda da ilk kamu spotunda olduğu gibi erkek özne ön plandadır. Ağırlıklı olarak erkeğin ailesine düşkün, koruyucu, sahiplenici özelliklerine atıfta bulunarak ataerkil yapıda evin düzenini sağlayan ve koruyan erkek modeli pekiştirilmektedir. Toplumsal cinsiyet eşitliği kadın ve erkeğin toplumda imkanlardan eşit şekilde yararlanmaları ve eşit haklara sahip olmaları anlamına gelmektedir. Toplumsal cinsiyet açısından film incelendiğinde burada kadınlarla erkeklerin eşit şekilde temsil edilmediği gözlenmektedir. Kadının sunuluş biçimi kadın ve erkek kimliğinin yeniden inşasına aracılık etmektedir. Bu yüzden filmlerde kadının temsil edilmemesi veya edilgen temsili filmin şiddete yönelik bilişsel algıyı değiştirme amacıyla çelişmektedir. Ayrıca toplumsal cinsiyet biyolojik cinsiyet farklılığına indirmeksizin kadın ve erkeğe verilen rolleri, iki cinsin sosyal ve kültürel tanımlamalarını ve aralarındaki farklılıkları belirleme biçimini anlatmak için kullanılan bir kavramdır. Biyolojik cinsiyet doğuştandır ama toplumsal cinsiyet toplumsallaşma sürecinde öğrenilir. Filmde hayvan metaforu ile insan karşılaştırılarak tamamen biyolojik, içgüdüsel tanımlamalara yer verilmiştir. Günümüzde artık cinsiyet eşitliği sorununu biyolojik farklılıklardan ziyade öğrenilmiş toplumsal davranışlar üzerinden ele alan toplumsal cinsiyet temelli bir bakış açısı gerekmektedir.

\section{3. "Hangi yüzle” İsimli Kamu Spotunun Göstergebilimsel Çözümlemesi}

24 Kasım 2017 tarihli kamu spotunun anlatım düzleminde, anlatının metni üreten öznesi KADEM (Ö1)'dir. Propp'un anlatı modeline göre burada koca, saldırgandır. Propp, saldırganın işlevlerini şöyle tanımlamaktadır: Saldırgan aileden birine zarar verir, kişilerin bedenlerine zarar verir, kurbanını bir şey yapmaya zorlar ya da zorla ondan birşey koparır, saldırgan birini öldürür, birini bir yere kapatır veya hapseder, saldırgan her gece birine zarar verir.

\subsection{1. “Hangi yüzle” İsimli Kamu Spotunun Dizimsel Çözümlemesi}

\section{Anlatı durumu:}

1. Evre: Bu kesitte erkek özne (Ö2) nin olumlu özellikleri yansitılmaktadır. İşyerine gelişle film başlar. Burada erkek, samimi, güleryüzlüdür: Asansörde karşıdan gelene kapıyı tutma, yanlışlıkla çarptığı kişiden özür dileme, patronuna gülümseyerek yanıt verme, çayı döken çaycıyı teskin etme, garajda başka bir aracı sabırla bekleme gibi (bkz. Görsel 1-14).

2. Evre: İşten çıkıp eve gitme sahnesi. Burada erkek öznenin olumsuz özellikleri yansıtılmaktadır: Eşine öfkeyle bakarak içeri girer, dışarıda gösteremediği öfkesini karısına göstermeye başlar. Yemek masasında eşine bağırır (sessel gösterge): "Yeter! Yeter artık! Gene söyledim. Herşeyden bıktım bu sabah be! Huzur yok! Nereye gidiyorsun ha!". Tabak kırar (Görsel 15-22). Burada yardımcılar soyut kavramlardır: tahammülsüzlük, öfke, şiddet, saldırganlık.

3. Evre: Kadın kendini odaya kilitler, adam üzerine yürür, kapıyı yumruklar. Burada nesne ikiyüzlülüktür (Görsel 23-32).

4. Evre: Metnin sözceleme öznesi KADEM'in eylemi değerlendirilmesiyle film sona erer: "Başkalarına göstermekten utanç duyduğun bir yüzün var. Sevdiklerine göstermekten çekinmiyorsun. Sevdiklerine hangi yüzle bakıyorsun?” (Görsel 33-34). 
Resim 3. "Hangi Yüzle" kamu spotundan kareler
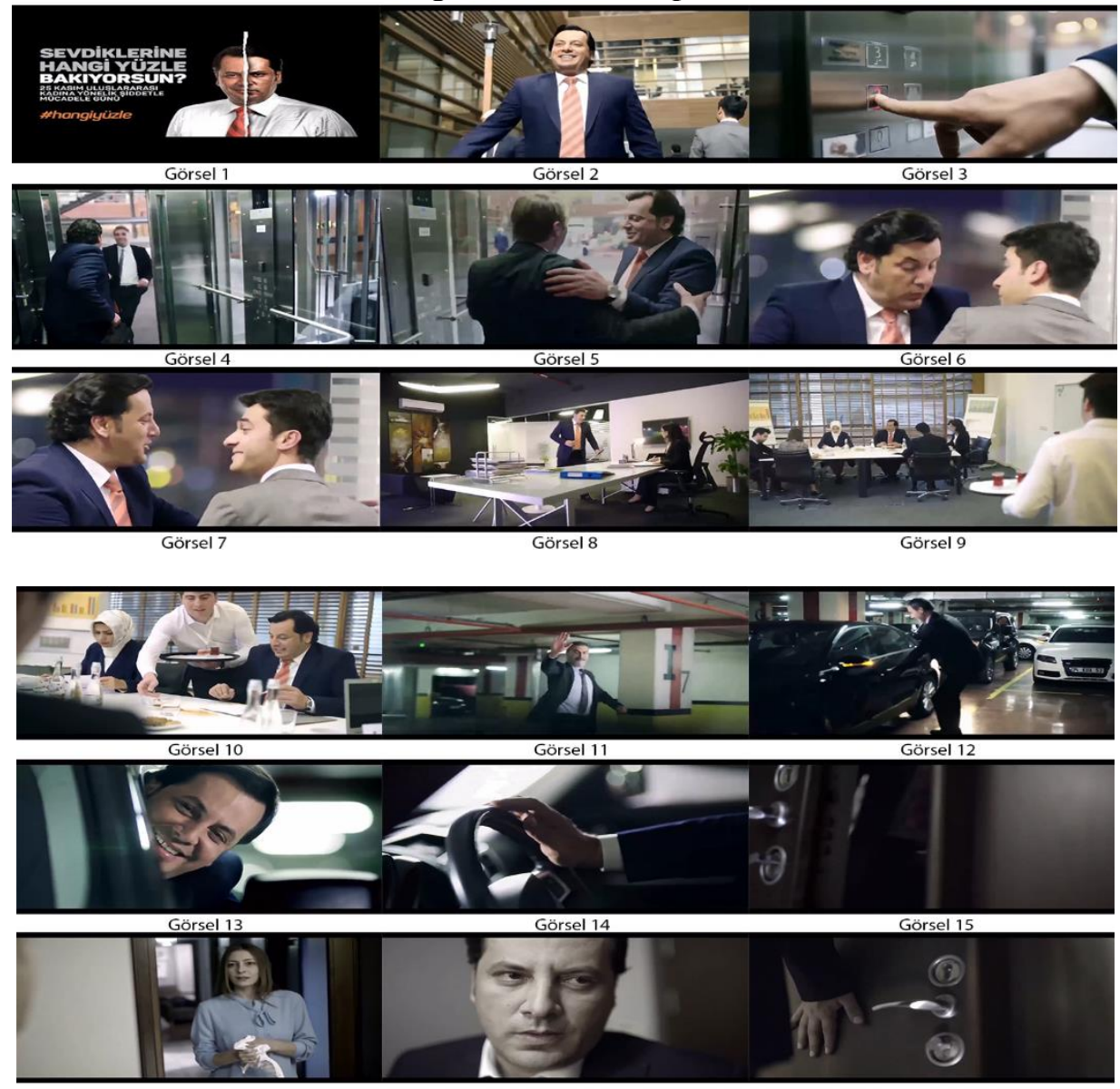

Görsel 16

Görsel 17

Görsel 18
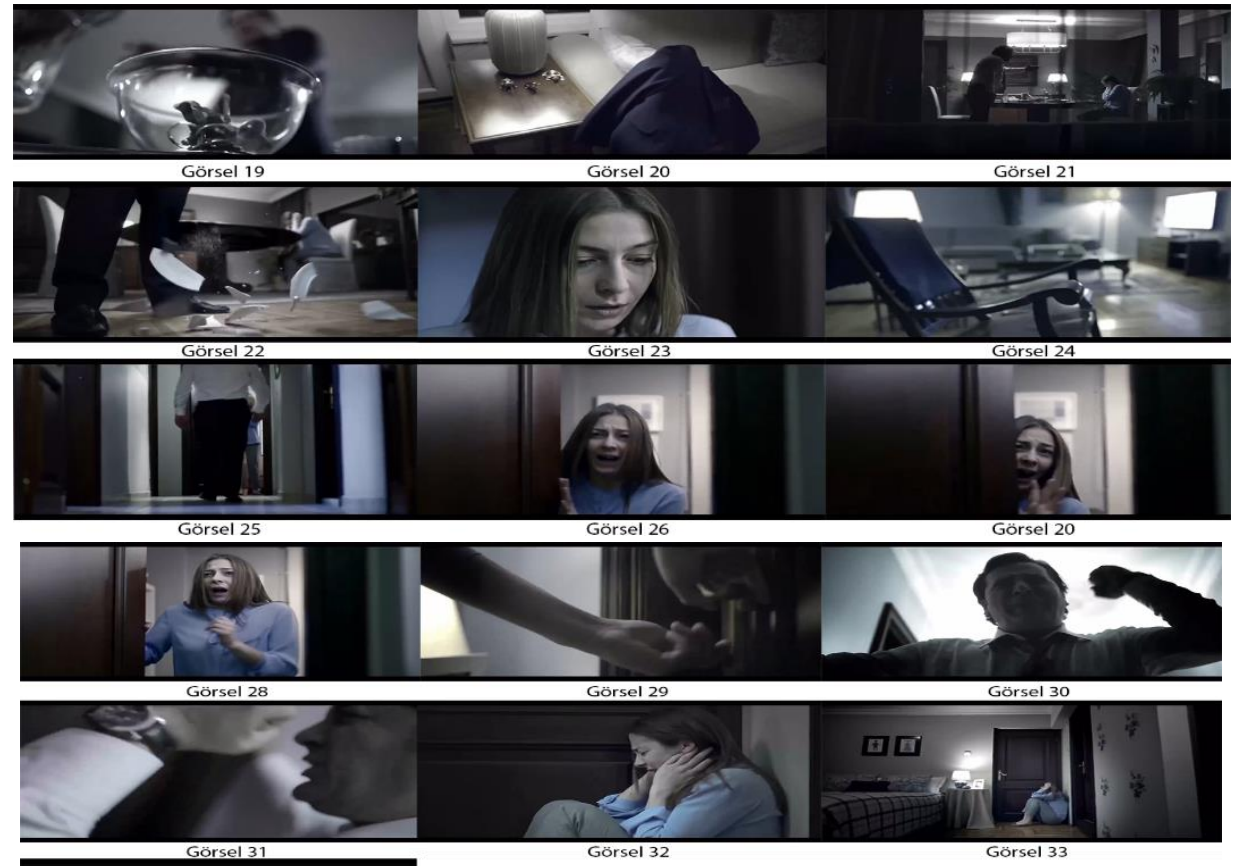

\#hangiyüzle

KADEM 
Tablo 6. Eyleyenler ve eyleyensel işlevler

\begin{tabular}{|c|c|c|}
\hline Eyleyenler & & Eyleyensel İşlevler \\
\hline Gönderen & Koca (kötü adam, saldırgan) & Eylemi belirleyen kişi \\
\hline Nesne & İkiyüzlülük & Eylemin konusu \\
\hline Gönderilen & Koca & $\begin{array}{l}\text { Eylemin kendisi } \\
\text { gerçekleştiği kişi }\end{array}$ \\
\hline Özne & Koca (kötü adam, saldırgan) & Eylemi yapar \\
\hline Engelleyici & Yok & Eylemi engeller \\
\hline Yardımcı & $\begin{array}{l}\text { Tahammülsüzlük, } \\
\text { şiddet, saldırganlık }\end{array}$ & Eyleme yardım eder \\
\hline
\end{tabular}

\subsection{2. “Hangi yüzle” İsimli Kamu Spotunun Dizisel Çözümlemesi}

Filmde karşıtlıklar aynı kişinin farklı davranışları üzerinden gösterilmektedir. Güleryüzlü ve anlayışlı olan da şiddet uygulayan da aynı kişidir. Farklı davranış kalıpları içindeki erkeğin hem olumlu kişilik özellikleri hem olumsuz kişilik özellikleri yansitılarak tutarsızlığ vurgulanmıştır. Şiddet dışı ve şiddet içeren öğeler görsellerle desteklenmiştir (Tablo 7).

Tablo 7. Kamu spotundaki karşıtlıklar

\begin{tabular}{ll}
\hline Karşıtlıklar & \\
\hline Pozitif & Negatif \\
Nazik & Kaba \\
Bağışlayıcı & Kindar \\
Saygılı & Saygısız \\
Anlayışılı & Anlayışsız \\
Sakin & Öfkeli \\
İçine atma & Dişavurum \\
Barış̧̧1 & Saldırgan \\
\hline
\end{tabular}

\section{Yorum}

İncelenen diğer kamu spotlarında olduğu gibi bu kamu spotunda da erkek özne aktif, kadın özne pasif gösterilmektedir. Kadına evde ev işleriyle uğraşan ve akşam kocasını bekleyen bir rol verilirken, erkek iş yaşamında yoğun tempoda çalışan iş adamı rolündedir. Burada da erkeğin çalışıp evini geçindirdiği kadınınsa ev işleri ile ilgilendiği ataerkil yapıya uygun özellikler göze çarpmaktadır.

\section{Sonuç ve Öneriler}

Ülkemizde kadına şiddet önemli sorunlarımızın başında gelmektedir. Tüm dünyada kadınlar eşleri, aile bireyleri veya erkek arkadaşları tarafından çeşitli sebeplerle şiddete maruz kalmaktadır. Ülkemizde genellikle kadına şiddet ataerkil bir toplum yapısından kaynaklanmaktadır. Şiddetin temelindeki sorun, kadın ve erkek arasındaki eşitsiz güç ilişkilerinde yatmaktadır. Bu eşitsiz güç ilişkilerini anlayabilmek için çocukluktan yetişkinliğe kadar giden sosyalizasyon sürecinde toplumun zihniyetinde oluşturulan cinsiyet algısının temellerine bakılmalıdır. Kadın erkek eşitliğine inanan erkeklerin yetişmesi, sağlıklı ve huzurlu bir toplum için en önemli kriterlerdendir. Bu açıdan, şiddetle mücadelede medyanın konuyu ele alışı ve sunumu bilişsel algılarımızın değişiminde önemli role sahiptir. Çalışmanın örneklemini oluşturan T.C. Aile ve Sosyal Politikalar Bakanlığı ve KADEM'in hazırladığı kamu spotlarında şiddetin, şiddeti gerçekleştiren kişi ve kadınların betimlemesinin feodal yapıya uygun bir şekilde yapıldığı görülmektedir. Kamu spotlarındaki görsel ve söylemlerdeki betimlemeler ağırlıklı olarak "itaat etme", "boyun eğme", "söz dinleme" şeklinde yapılmıştır. Filmlerdeki temel sorun, ataerkil toplum özelliklerine uygun olarak erkek egemen özellikler pekiştirilmektedir. Kadına şiddetin çözümünde yalnızca erkek davranışlarına odaklandığı görülmektedir. Şiddetin arka planındaki toplumun feodal yapısını irdeleyen bir mesaj yer almamaktadır. Sorunun temelinde yer alan 
eşitsiz güç ilişkilerinin zihinsel, sosyolojik, psikolojik, ekonomik nedenleri göz ardı edilmektedir. Nitekim ülkemizde gerçekleştirilen sayısız kadın cinayetleri her seferinde toplumca kınanmasına rağmen bu cinayetler gerçekleşmeye devam etmektedir ve çoğunda eşini öldürenler bir pişmanlık duymamaktadır.

Erkek ve kadının toplum işlerini düzenlerken beraber hareket etmeleri, eşitlik ve tamamlayıcılık anlayışı içerisinde aralarındaki farklılıklarla yapılan işleri zenginleştirmeleri, toplumdaki cinsiyet farklılıklarının azalmasında büyük öneme sahiptir. Evde ve iş yerinde iktidar sahibi olan erkek kazanç dengesi açısından kadın için eşitsiz bir durum oluşturabilmektedir. Kamu spotlarında gizlenmiş iktidar ilişkisi toplumsal cinsiyet bağlamında yansıtılırsa, kadının ekonomik ve toplumsal bağlamda eşitliği için bir mesaj verilebilir. Esasında bu filmler, kadının ev işleri ile ilgilenmesi erkeğin de iktidar ve yüksek otoriteye sahip olmasına dayalı kalıp yargıları örtük olarak sunarak kadının ekonomik, psikolojik şiddete de maruz kaldığı gerçeğini anımsatmaktadır. Toplum gelenek göreneklerine göre kadına biçilen rolü ön plana çıkartmak yerine kadının da erkek gibi çalışan, bilim ve sanat gibi kollarda faaliyet gösteren rollerde sunumu cinsiyet ayrımcılığı ve şiddetle mücadele açısından önem arz etmektedir. Kadınlara yönelik şiddete karşı projeler, yasal düzenlemeler ve bu düzenlemeler hazırlanırken çeşitli mesleklerden kadınların da dahil olması, tutum değişiklikleri için medya kampanyaları, şiddet gören kadınları desteklemek, erkeklerin bu konuda eğitilmesi gibi birçok önlemi biraraya getirecektir. Şiddete toplumsal cinsiyet temelli bakılabilirse bu projelerin kapsamı da artacaktır.

Medya kampanyaları, kadına yönelik şiddeti daha çok vurgular ve çok yönlü yansıtırsa şiddetin önlenmesinde toplumsal bir değişiklik oluşabilir. Bunun örnekleri dünyada görülebilmektedir. Medya dili olarak, kadın ile erkeğin arasındaki farkların doğuştan geldiğini savunan ve kadını ikincilleştiren, kadının yeri evidir görüşünü destekleyen, çalışma yaşamında kadın ve erkeklerin yapacă̆ işleri sınıflandırıcı, ifadelere yer verilmemesi önem arz etmektedir. Ayrıca şiddetin kökeni sadece geleneklere dayandırılmayıp, çok daha derin olan sosyo ekonomik ve psikolojik boyutlara bakılmalıdır. Kadının emeğinin sömürülmesi, iş yaşamında mobbinge maruz kalması da kadının uğradığı şiddete örnektir. Dolayısıyla, şiddetle mücadele kapsamında hazırlanan kamu spotlarının konuyu bu çerçevede genişleterek, şiddetin her türüne dikkat çekmesinin mücadelede daha etkili olacağı düşünülmektedir.

\section{Kaynakça}

Akerson, E. F. (2005). Göstergebilime Giriş, Multilingual Yayınc1lık, İstanbul.

Aksu B. ve Üstün, İ. (2005). Sicak Aile Ortamı, Demokratikleşme Sürecinde Kadın ve Erkekler, İstanbul :TESEV Yayınları.

Atakul, S., (2002). Toplumsal Cinsiyet Eşitliği ve Ulusal Medya Politikaları, Şiddet ve Intihar Haberlerinin Sunumunun Toplum Üzerindeki Etkileri Sempozyumu, Ankara: RTÜK Yayın No:6, 55-63.

Bator, R. J., ve Cialdini, R. B. (2000). New Ways to Promote Proenvironmental Behavior: The Application of Persuasion Theory to the Development of Effective Proenvironmental Public Service Announcements, Journal of Social Issues 56(3): 527-41.

Baygal, A. (2016). Şiddetin Aile İçi Görünümleri, İçinde: Değişen Toplumda Değişen Aile (Ed: N. Adak), Ankara: Siyasal Kitabevi.

Bilton, T., Bonnett, K.ve Jones P. (2009). Toplumsal Cinsiyet İlişkileri, İçinde: Sosyoloji (Ed.B. Özçelik), Ankara: Siyasal Kitabevi.

Binark, M ve Gencel, B. (2007). Yeni Medya Çalışmalarında Yeni Sorular ve Yöntem Sorunu, Yeni Medya Çalışmaları (Der:M. Binark ), Ankara: Dipnot Yayınları.

Bütün, M., Selçuk, M. , Akadal, E. ve Gülseçen, S. (2018). Kamu Spotlarının Etkililiği Üzerine Bir Araştırma, Selçuk İletişim, 11 (2): 273-291. 
Canada: Immigration and Refugee Board of Canada, Cameroon: Domestic violence, including legislation; protection provided by the state and support services available to victims (20142016) (2016). http://www.refworld.org/docid/5729a55e4.html (Erişim tarihi: 21 Şubat 2019)

Canikoğlu, S., K. (2015). Kadınlara Yönelik Şiddetin ve Ev İçi Şiddetin Önlenmesine Dair Ulusal ve Uluslararası Mevzuat (İstanbul Sözleşmesi ve 6284 Sayılı Kanun, Ankara Barosu Dergisi, (3): 356-378.

Cialdini, R. B. 2003. Crafting Normative Messages to Protect the Environment, Current Directions in Psychological Science 12 (4):105-9.

Cins var, cins var (2017). KADEM'den 25 Kasım Uluslararası Kadına Yönelik Şiddetle Mücadele Günü Videosu, youtube: https://www.youtube.com/watch?v=vyj0VWllEkw (Erişim tarihi: 02.12.2018).

Çalışkan H ve Çevik E., İ. (2018). Kadına Yönelik Şiddetin Belirleyicileri: Türkiye Örneği, Balkan Sosyal Bilimler Dergisi, 7(4).

Dillard, J. P. ve Peck, E. (2000). Affect and Persuasion Emotional Responses to Public Service Announcements, Communication Research, 27(4): 461-495.

Ediz, A. ve Altan Ş. (2017). Türkiye'de Kadına Yönelik Şiddet Üzerine Bir Alan Araştırması, TBB Dergisi, http://tbbdergisi.barobirlik.org.tr/m2017-2017-1729.

Göçmen, T.L. ve Ayvaz, S. (2017). Kamu Spotlarının Göstergebilimsel Yöntemle Çözümlenmesi: Sağlık Bakanlığı Örneği, Anadolu Üniversitesi İletişim Bilimleri Fakültesi Uluslararası Hakemli Dergisi, 25(2): 112-128.

Gödelek, K. (2005). Güç, İktidar İlişkisi Bağlamında Kadına Yönelik Şiddet, Muğla Üniversitesi Sosyal Bilimler Enstitüsü Dergisi, (15).

Gökkaya, V., B. (2011), Türkiye'de Kadına Yönelik Ekonomik Şiddet, Cumhuriyet Üniversitesi Íktisadi ve İdari Bilimler Dergisi, 12(2): 103.

Greimas, A. J. (1988). Maupassant: the Semiotics of Text : Practical Exercises, Edit: Landowski, E, (Translated: Peron, P.), Amsterdam/Philadelphia: John Benjamins Publishing Company.

Griskevicius, V. Cialdini, R. B. ve Goldstein, N. J. (2008), Social Norms: An Underestimated and Underemployed Lever for Managing Climate Change. International Journal of Sustainability Communication, 3 (2008):5-13.

Gülada, M. O. (2018). Korku Çekiciliği Kavramının Trafik Kazalarını Konu Alan Kamu Spotu Reklamlarında Kullanımı, Uluslararası Sosyal Bilimler Dergisi, 1(2): 131-143.

Güngör, N. (2011), Illetişim- Kuramlar-Yaklaşımlar, Ankara: Siyasal Kitabevi.

KADEM reklam filmi- Karşındakine Hangi Yüzle bakıyorsun!! (2017). youtube: https://www.youtube.com/watch?v=a1Io2siL6tE (Erişim tarihi: 02.12.2018).

KADEM (2018). http://kadem.org.tr/kadem-i-olagan-genel-kurul-ve-tanitim-toplantisi/ (Erişim tarihi: 21 Şubat 2019).

Kadına Şiddet İnsanlığa İhanettir (2017). Kadına Şiddet İnsanlığa İhanettir! Kamu Spotu, youtube: https://www.youtube.com/watch?v=PgInQeJlJEI (Erişim tarihi: 02.12.2018).

Kadına Yönelik Şiddetin Sebeplerinin Araştırılarak Alınması Gereken Önlemlerin Belirlenmesi Amaciyla Kurulan Meclis Araştırması Komisyonu Raporu (2015). http://www.tbmm.gov.tr/sirasayi/donem24/yil01/ss717-bolum-2.pdf (Erişim tarihi: 02.12.2018). 
Karatay, A. ve Karatay, A. (2015), Sosyal Sorumluluk Bağlamında, Dünyada "Kadına Yönelik Şiddete Hayır” Temalı Sosyal Medya Kampanyaları ve Aktivizm Örnekleri, Uşak Üniversitesi Sosyal Bilimler Dergisi, 8(1): 21-36.

Keisler, A. (2016), Predictors of Effectiveness of Public Service Announcements (PSAs): A Systematic Analysis of Campaigns, Marketing and Public Policy Conference Proceedings.

Kıran, A. ve Kıran, Z. (2011), Yazınsal Okuma Süreçleri, Dilbilim, Göstergebilim ve Yazınbilim Yöntemleriyle Çözümlemeler, Ankara: Seçkin Yayınları.

Kocacık, F. (2004). Aile İçi İlişkilerde Kadına Yönelik Şiddet: Türkiye’den Örnekler, Sivas Cumhuriyet Üniversitesi.

Köse, A. ve Beşer, A. (2007), Kadının Değiştirilebilir Yazgısı "Şiddet", Atatürk Üniversitesi Hemşirelik Yüksekokulu Dergisi, 10(4): 114-121.

Mor Çatı (2018) . https://www.morcati.org.tr/tr/tanisalim/oykumuz (Erişim tarihi: 02.12.2018)

My Voice Short Film Against Gender Based Violence (2017). https://www.youtube.com/watch?v=5UrXg3_VZLU (Erişim tarihi: 02.12.2018).

Oktay, E.Y. (2015). Türkiye'nin ve Dünyanin Ortak Sorunu: Kadina Şiddet, Akademik Araştırmalar Dergisi, (64): 57-118.

Özbük, M. ve Öz, Y. (2017). Türkiye'de Yayınlanmış Olan Kamu Spotlarının İçerik Analizi Yöntemi ile İncelenmesi, Business and Economics Research Journal, 8(3): 575-589.

Parmaksızoğlu, A. (2011). Aile İçi Şiddet Mağduru Olup Boşanma Sürecinde Bulunan Kadınlarda Travma Sonrası Stres Belirtileri ve İlişkili Özellikler, Kocaeli: Yayımlanmamış Yüksek Lisans Tezi.

Propp, V. (1985). Masalın Biçimbilimi, (Çev.: M. Rıfat ve S. Rıfat), İstanbul: Bilim Felsefe Sanat Yayınlar1.

Rıfat, M. (2011). Homo Semioticus ve Genel Göstergebilim Sorunları, İstanbul: Yap1 Kredi Yayınlar1.

Soydan, M. (2007). Yavuz Turgul'un Gönül Yarası Filminin Greimas'ın Eyleyensel Örnekçesine Göre Çözümlenmesi, Sosyal Bilimler Dergisi, (18): 1-14.

Staggers, S. M. ve Myers, S. (2011). Working to Alleviate Gendered Violence on College Campuses by Designing Public Service Announcement Storyboards, Communication Teacher, 25(4): 212-217.

Şeker, M., ve Tiryaki, S. (2013). Sigara ile ilgili kamu spotlarında moral panik etkisi. Selçuk Üniversitesi Türkiyat Araştırmaları Dergisi, 223-241.

Tanca, H. A. ve Ünal, F. (2018). Kitap Okuma Kültürü Konulu Kamu Spotunun Göstergebilimsel Analizi, Uluslararası Sosyal Araştırmalar Dergisi, 721-728.

Terkan, B. (2010). Kadın Örgütlerinin İnterneti Alternatif Medya Olarak Kullanımı Üzerine Bir İnceleme, Selçuk Üniversitesi İletişim Fakültesi Dergisi, 6 (3): 34-55.

Türkiye'de Kadına Yönelik Aile İçi Şiddet Araştırması (2017). http://www.hips.hacettepe.edu.tr/KKSATRAnaRaporKitap26Mart.pdf (Erişim tarihi: 02.12.2018).

Uyar, M.,Öztürk, E., Y. Ve Şahin, T. K. (2018). Kadına Yönelik Şiddete Genel Bir Bakış, Akademik Sosyal Araştırmalar Dergisi, (71): 154-162.

van Der Gaag, N.(2018). Feminizm (çev. B.S.Aydaş), İstanbul: Sel Yayıncılık.

WHO, http://www.who.int/gho/women_and_health/violence/en/), (Erişim tarihi: 27.08.2018). 
WHO, http://www.who.int/news-room/fact-sheets/detail/violence-against-women, (Erişim tarihi: 05.12.2018)

Yaman, F., ve Göçkan, İ. (2015). Kamu spotu reklamlarının sigara kullanıcıları üzerindeki etkisi: Afyonkarahisar ilinde bir Uygulama, KAÜ IIIBF Dergisi, 6(11): 53-65. 